\title{
DNA import competence and mitochondrial genetics
}

\author{
F. Weber-Lotfi ${ }^{1}$, D. V. Mileshina ${ }^{1,2}$, N. Ibrahim ${ }^{1,3}$, M. V. Koulintchenko ${ }^{1,2,3}$, \\ G. G. M. D'Souza ${ }^{4}$, V. Saxena ${ }^{4}$, Yu. M. Konstantinov ${ }^{2}$, R. N. Lightowlers ${ }^{3}$, A. Dietrich ${ }^{1}$
}

${ }^{1}$ Institute of Plant Molecular Biology, CNRS and University of Strasbourg (UdS)

12, General Zimmer Str., Strasbourg, France, 67084

${ }^{2}$ Siberian Institute Plant Physiology and Biochemistry, Siberian Branch of the RAS

132, Lermontova Str., Irkutsk, Russian Federation, 664033

${ }^{3}$ Institute for Cell and Molecular Biosciences, Medical School, Newcastle University

Framlington Place, Newcastle upon Tyne, UK, NE2 4HH

${ }^{4}$ School of Pharmacy, MCPHS University,

179, Longwood Ave., Boston, USA, MA 02115

andre.dietrich@ibmp-cnrs.unistra.fr

\begin{abstract}
Aim. To understand the mechanism(s) underlying mitochondrial competence for DNA uptake and to exploit these pathways for the development of in vivo models of gene therapy. Methods. DNA uptake into isolated mitochondria from plant or from mutant Saccharomyces cerevisiae defective for mitochondrial proteins and carriers, biochemical approaches and transfection of mammalian cells with DNA bound to mitochondriotropic liposomes. Results. Special focus on the inner membrane showed the involvement of isoforms of the adenine nucleotide translocator and the contribution of proteins controlling mitochondrial morphology in DNA uptake into yeast organelles. Transfection assays led to significant incorporation of a mitochondrial construct into mammalian cells and expression of a marker gene. Conclusions. The data imply that there are multiple mitochondrial DNA import pathways. On the other hand, preliminary results suggest that mitochondriotropic liposomes can deliver DNA to mitochondria in live mammalian cells.
\end{abstract}

Keywords: mitochondria, DNA import, mitochondrial transfection, plant, Saccharomyces cerevisiae, mammal.

Introduction. Mitochondrial genome expression is essential for organelle functional efficiency and intercompartment cross-talk. Manipulation of mitochondrial genetics is thus of interest for a range of fundamental investigations and is appealing to treat neurodegenerative diseases caused by organelle DNA mutations. In plants, mitochondrial genetics underlies key breeding tools. Given the importance of these issues, transforming mitochondria has been a long standing goal that was unfortunately reached only in a couple of unicellular organisms. Contrasting with the failure to transform the organelles in whole cells, we established that isolated plant and mammalian mitochondria can functionally import double-stranded DNA through an active mechanism [1,

(C) Institute of Molecular Biology and Genetics, NAS of Ukraine, 2014
2]. The process is sensitive to a number of effectors and can accommodate large size linear DNA [3]. Remarkably, the imported DNA functionally joins the organelle genetic system. Marker sequences under the control of a mitochondrial promoter are expressed in organello $[1,2]$. Imported DNA carrying oxidative lesions is repaired $[4,5]$. Constructs carrying fragments of mitochondrial DNA undergo homologous recombination with the resident DNA [6]. On that basis, we aim to understand the mechanism(s) underlying mitochondrial competence for DNA uptake and to develop cell uptake followed by mitochondrial targeting of functional gene constructs.

Materials and methods. We developed DNA uptake experiments with mitochondria isolated from potato (Solanum tuberosum) or from Saccharomyces cerevisiae mutants defective for various nucleus-encoded mi- 
tochondrial proteins and carriers. We used $1-2.3 \mathrm{~kb}$ radiolabeled DNA fragments as substrates. Isolation of mitochondria and uptake assays were performed as described earlier [1,7]. For mitochondrial targeting of DNA in mammalian cells, a liposomal formulation was prepared by a standard film hydration method [8]. A $2.2 \mathrm{~kb}$ DNA construct was complexed with the liposomal carrier and incubated with a rat cell culture. qPCR and RT-qPCR analyses assessed the level of cell-internalized construct and putative transcription.

Results and discussion. The voltage-dependent anion channel (VDAC) seems to be involved in DNA translocation through the mitochondrial outer membrane [1, $2,7]$. For the inner membrane, inhibition studies of the uptake using specific effectors pointed to an involvement of the adenine nucleotide translocator in plants [1], but the challenge of understanding which channel(s) can be recruited or hijacked by double-stranded DNA molecules remains mostly open. In the present studies, we used both biochemical approaches and $S$. cerevisiae genetic tools to identify the still elusive inner membrane proteins participating in mitochondrial DNA import. Strikingly, among the candidates from the inner membrane carrier family selected on the basis of biochemical data with plant organelles, only the two minor forms of the adenine nucleotide translocator turned out to be required for optimal DNA translocation into isolated yeast mitochondria (Figure). Conversely, we highlighted a putative contribution of proteins that control mitochondrial morphology in $S$. cerevisiae.

Building on the hypothesis that the competence for DNA uptake is also a property of the organelles in vivo, we attempted to use nanocarriers to target DNA to mitochondria in intact cells. We explored the use of a mitochondriotropic liposomal formulation to deliver a DNA construct encoding a recoded green fluorescent protein (gfp) gene controled by a rat mitochondrial promoter into the mitochondria in live rat cells. In comparison to free DNA and vehicle controls, incubation of the cells with liposome/DNA complexes led to significant incorporation of the construct and generation of gfp mRNA.

Conclusions. Taken together, our data imply that there are significant variations in the mitochondrial DNA import mechanism between different organisms and that even in a given organism multiple pathways might operate. Our first in vivo results suggest that mitochond-
Incubation of mitochondria with radiolabeled dsDNA
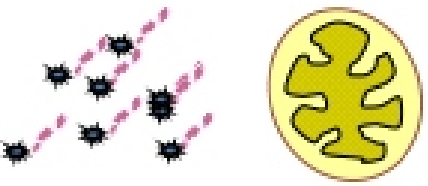

DNase I treatment

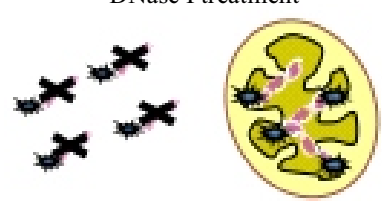

Nucleic acid extraction and analysis by Southern blot

$B$ Parental

$\Delta a a c$ 1, 2, 3

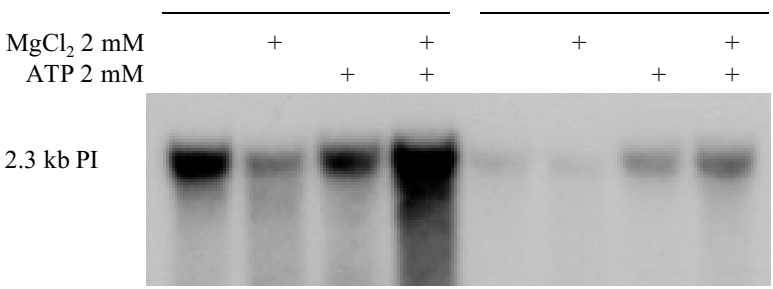

DNA import into mitochondria from $S$. cerevisiae deleted for the three isoforms of adenine nucleotide translocator $(\Delta a a c 1,2,3)$ is impaired: $A$ - scheme of an in vitro DNA import assay with isolated mitochondria (dsDNA: double-stranded DNA); $B$ - import of radiolabeled Zea mays $2.3 \mathrm{~kb}$ mitochondrial linear plasmid into isolated mitochondria from the parental or the deleted $S$. cerevisiae strain, without or with addition of $\mathrm{MgCl}_{2}$ and /or ATP in the reaction medium. Migration of the $2.3 \mathrm{~kb}$ import substrate is indicated by an arrow. Addition of ATP and $\mathrm{MgCl}_{2}$ still enhances DNA import into mitochondria from the deleted strain. When using mitochondria isolated from an $S$. cerevisiae strain deleted for only the major form of the adenine nucleotide translocator ( $\triangle a a c$ 2), DNA import was not affected (not shown)

riotropic liposomes can deliver DNA into mitochondria of live mammalian cells, potentially opening novel prospects for mitochondrial transfection.

Funding. This work was supported by regular funding from the CNRS and the University of Strasbourg, as well as by the Investissements d'Avenir from the French Ministry for Research (grant number ANR-11-LABX0057_MITOCROSS).

Природна здатність мітохондрій до імпорту ДНК

і мітохондріальна генетика

Ф. Вебер-Лотфі, Д. В. Мілешина, Н. Ібрагім,

М. В. Кулінченко, Г. Г. М. Дсуза, В. Саксена,

Ю. М. Константинов, Р. Н. Лайтауерс, А. Дитриш

Резюме

Мета. Визначити механізми поглинання ДНК мітохондріями і використати їх для удосконалення існуючих моделей генної терапї 
in vivo. Методи. Поглинання ДНК ізольованими мітохондріями рослин або мітохондріями мутантних ліній Saccharomyces cerevisiae, дефектних за мітохондріальними білками та переносниками, біохімічні підходи і трансфекиія в клітини ссавиів ДНК, зв 'язаної $з$ мітохондріотропними ліпосомами. Результати. Основним підсумком вивчення внутрішньої мембрани виявилося встановлення того факта, щзо до процесу перенесення ДНК дріжджсовими органелами залучені кілька ізоформ аденіннуклеотидтранслокази, а також білки, які контролюють мітохондріальну морфологію. В експериментах з трансфекиії ДНКу клітини ссавиів виявлено вбудовування в них мітохондріальної конструкиії і експресію маркерного гена. Висновки. Отримані дані дозволяють припустити існування декількох механизмів імпорту ДНК у мітохондрії. Проте $\epsilon$ попередні результати, які показують, щуо мітохондріотропні ліпосоми можуть бути використані для доставки ДНК у мітохондріі клітин ссавців іп vivo.

Ключові слова: мітохондрія, імпорт ДНК, трансфекиія мітохондрій, рослина, Saccharomyces сегеvisiae, ссавець.

Природная способность митохондрий к импорту ДНК

и митохондриальная генетика

Ф. Вебер-Лотфи, Д. В. Милешина, Н. Ибрагим,

М. В. Кулинченко, Г. Г. М. Дсуза, В. Саксена,

Ю. М. Константинов, Р. Н. Лайтауэрс, А. Дитриш

\section{Резюме}

Цель. Выяснить механизмы поглощения ДНК митохондриями и использовать их для усовершенствования существующих моделей генной терапии in vivo. Методы. Поглощение ДНК изолированными митохондриями растений или митохондриями мутантных линий Saccharomyces cerevisiae, дефектных по митохондриальным белкам и переносчикам, биохимические подходы и трансфекция в клетки млекопитающих ДНК, связанной с митохондриотропныли липосомами. Результаты. Основными итогом изучения внутренней мембраны оказалось установление того факта, что в процесс переноса ДНК дрожжевыми органеллами вовлечены несколько изоформ адениннуклеотидтранслоказы, а также белки, контролируюшие митохондриальную морфологию. В эксперименmax по трансфекции ДНК в клетки млекопитаюших выявлены встраивание в них митохондриальной конструкции и экспрессию маркерного гена. Выводы. Полученные данные позволяют пред- положить существование нескольких механизмов импорта ДНК в митохондрии. Однако есть предварительные результаты, показывающие, что митохондриотропные липосомы могут быть использованы для доставки ДНК в митохондрии клеток млекопитающих in vivo.

Ключевые слова: митохондрия, импорт ДНК, трансфекиия митохондрий, растение, Saccharomyсеs сегеvisiae, млекопитающее.

\section{REFERENCES}

1. Koulintchenko M, Konstantinov Y, Dietrich A. Plant mitochondria actively import DNA via the permeability transition pore complex. EMBO J. 2003; 22(6):1245-54.

2. Koulintchenko M, Temperley RJ, Mason PA, Dietrich A, Lightowlers $R N$. Natural competence of mammalian mitochondria allows the molecular investigation of mitochondrial gene expression. Hum Mol Genet. 2006; 15(1):143-54.

3. Ibrahim N, Handa H, Cosset A, Koulintchenko M, Konstantinov $Y$, Lightowlers RN, Dietrich A, Weber-Lotfi F. DNA delivery to mitochondria: sequence specifity and energy enhancement. Pharm Res. 2011; 28(11):2871-82.

4. Boesch P, Ibrahim N, Paulus F, Cosset A, Tarasenko V, Dietrich $A$. Plant mitochondria possess a short-patch base excision DNA repair pathway. Nucleic Acids Res. 2009; 37(17):5690-700.

5. Boesch P, Ibrahim N, Dietrich A, Lightowlers RN. Membrane association of mitochondrial DNA facilitates base excision repair in mammalian mitochondria. Nucleic Acids Res. 2010; 38(5): 1478-88.

6. Mileshina D., Koulintchenko M., Konstantinov Y., Dietrich A. Transfection of plant mitochondria and in organello gene integration. Nucleic Acids Res. 2011; 39(17):e115.

7. Weber-Lotfi F, Ibrahim N, Boesch P, Cosset A, Konstantinov $Y$, Lightowlers RN, Dietrich A. Developing a genetic approach to investigate the mechanism of mitochondrial competence for DNA import. Biochim Biophys Acta. 2009; 1787(5):320-7.

8. Boddapati SV, Tongcharoensirikul P, Hanson RN, D 'Souza GG, Torchilin VP, Weissig V. Mitochondriotropic liposomes. J Liposome Res. 2005; 15(1-2):49-58. 